Meta

Journal des traducteurs

Translators' Journal

\title{
Translation in China: A Motivating Force
}

\section{Wang Kefei et Shouyi Fan}

Volume 44, numéro 1, mars 1999

Théorie et pratique de la traduction en Chine

The Theory and Practice of Translation in China

URI : https://id.erudit.org/iderudit/004591ar

DOI : https://doi.org/10.7202/004591ar

Aller au sommaire du numéro

Éditeur(s)

Les Presses de l'Université de Montréal

ISSN

0026-0452 (imprimé)

1492-1421 (numérique)

Découvrir la revue

Citer cet article

Kefei, W. \& Fan, S. (1999). Translation in China: A Motivating Force. Meta, 44(1), 7-26. https://doi.org/10.7202/004591ar

\section{Résumé de l'article}

Au cours de ses 5000 ans d'histoire, la Chine a connu quatre différentes vagues d'activité traductionnelle. La première a commencé avec la traduction des classiques bouddhistes par des moines d'Inde et d'Asie centrale et par des moines chinois à l'aise tant avec ces doctrines qu'avec le sanscrit. La traduction des écrits bouddhiques s'étale sur plus de 1000 ans (à partir de la fin de la dynastie Han) et a laissé des traces indélébiles sur la religion, la philosophie et la vie sociale en Chine. La deuxième vague de traduction débute à la fin de la dynastie Ming (fin du xvie siècle) quand les missionnaires jésuites arrivèrent de l'Occident pour prêcher le catholicisme et enseigner la science et la technologie. La signature imposée du traité de Nanking marque le début de la troisième vague qui se caractérise par la traduction d'ouvrages de sciences sociales, de science militaire et de littérature. Enfin, la dernière vague commence à la fin des années 1950, elle est interrompue par la révolution culturelle et reprend à la fin des années 1970. Dans un certain sens, la traduction a donné au pays une impulsion vers le progrès.
Ce document est protégé par la loi sur le droit d'auteur. L’utilisation des services d'Érudit (y compris la reproduction) est assujettie à sa politique d'utilisation que vous pouvez consulter en ligne.

https://apropos.erudit.org/fr/usagers/politique-dutilisation/ 


\title{
Translation in China: A Motivating Force
}

\author{
wang kefei and shouyi fan \\ Beijing Foreign Studies University and \\ Beijing Foreign Affairs College, Beijing, China
}

\begin{abstract}
RÉSUMÉ
Au cours de ses 5000 ans d'histoire, la Chine a connu quatre différentes vagues d'activité traductionnelle. La première a commencé avec la traduction des classiques bouddhistes par des moines d'Inde et d'Asie centrale et par des moines chinois à l'aise tant avec ces doctrines qu'avec le sanscrit. La traduction des écrits bouddhiques s'étale sur plus de 1000 ans (à partir de la fin de la dynastie Han) et a laissé des traces indélébiles sur la religion, la philosophie et la vie sociale en Chine. La deuxième vague de traduction débute à la fin de la dynastie Ming (fin du $x v I^{e}$ siècle) quand les missionnaires jésuites arrivèrent de l'Occident pour prêcher le catholicisme et enseigner la science et la technologie. La signature imposée du traité de Nanking marque le début de la troisième vague qui se caractérise par la traduction d'ouvrages de sciences sociales, de science militaire et de littérature. Enfin, la dernière vague commence à la fin des années 1950, elle est interrompue par la révolution culturelle et reprend à la fin des années 1970. Dans un certain sens, la traduction a donné au pays une impulsion vers le progrès.
\end{abstract}

\begin{abstract}
Four waves of translation activities have marked China's 5,000-year-long history. The first wave began with the translation of Buddhist classics by Indian and Central Asian Buddhist monks by Chinese monks conversant in both the doctrines and Sanskrit. The translation of Buddhist scriptures began in the late Han Dynasty and continued for more than 1,000 years, leaving a permanent influence on China's religion, philosophy and social life. The second wave of translating started in the late Ming Dynasty of the 16th century, when the Jesuit missionaries from the West came to China to spread Catholicism and teach science and technology. The signing, at gunpoint, of the Treaty of Nanking ushered in a third wave of translation activity, this one focused on works of social sciences, military sciences, and literature. The fourth wave of translation activity began in the late 1950s, was interrupted by the outbreak of the cultural revolution, but resumed its momentum in the late 1970s. In a sense, translation in China has served as a sort of motivating force, giving impetus to the country's progress.
\end{abstract}

\section{INTRODUCTION}

The earliest historical records show sporadic translation activities in China in the eleventh century B.C. But serious discussions on translation did not begin until the introduction of Buddhism into the country in the Six Dynasties (222-589) when Buddhist monks set about translating classics of Buddhism into Chinese. This first wave of translation activities lasted into the Tang (618-907) and Song (960-1279) Dynasties. The 1,000-year-long period can be divided into four stages illustrating the beginning, growth, climax, and conclusion of Buddhist translation activities. The most notable monastic translators of this period included An Shi-gao (active between 148-170), Dharmaraksa (232-309), Dao An (312 or 314-385), Fa Xian (335-420), Kumarajiva (350-409), Hsuan-tsang (600-664), among others. The translation of 
Buddhist works contributed to the spread of Buddhism, which would become one of China's major religions.

The second wave began in the late M ing and early Qing Dynasties around the 17th century when Jesuit missionaries from the West came to China to spread catholicism and teach science. This period lasted for a span of about 200 years. It was an age when science was gaining importance in the Western world. Had the oldfashioned elite had the foresight to follow the example of some liberal-minded intellectual officials and embrace the advances in science and technology that were changing the outlook of the Western countries, the history of modern China might have been quite different. This was not to be, but the translation of scientific works nevertheless left its mark on the history of modern China. The most remarkable achievements during these two centuries were the introduction of such basic sciences as mathematics, geometry and astronomy.

The third wave started when China was forced to open up to the imperialist powers from the West in the mid 19th century. M ilitary invasions, commercial adventures, and cultural influences from the West combined to make China's intelligentsia realize that China was no longer the Central Kingdom of the world, that they had much to learn from the West before imperialist rivals could be met on equal terms. Lin Zexu (1785-1850), the special imperial envoy to Guangdong province in 1838, was regarded as "the first Chinese who opened his eyes to look at the outside world." Believing that China must "learn from the strong points of the enemies in order to eventually conquer them," he organized a team of bilingual scholars to gather information from the Western press and have texts on the history and geography of foreign countries translated into Chinese.

Unlike the translation activities of the first and second waves which dealt with Buddhism and science respectively, activity in the third wave was focused on works of social and military sciences. However, towards the end of the 19th century, literary translation began to flourish. ${ }^{1}$ The translation of Western works had a phenomenal effect on the minds of the Chinese people, and a series of revolutionary movements ensued, sweeping across the country and over the centuries. The decadent feudal society was replaced by the Republic of China, which was in turn toppled to open the way to a new China. When we view the changes that have taken place in China and across the world, generations of translators have played an impressive role in shaping both the destinies of their own countries and their relations with other countries of the world. In a sense, translation can be regarded as a motivating force that promotes interaction between the family of nations in the historical process of moving towards a better world.

\section{TRANSLATION AND DISSEMINATION OF BUDDHIST TEXTSIN THE HAN DYNASTY}

\subsection{Translation of the Buddhist Scriptures}

Before it came to China, Buddhism, which is of Indian origin, had already undergone several centuries of development. Its impact upon the world was profound-it not only helped reshape man's outlook and way of life, but added a written script and unique art, literature, and philosophy to the common wealth of mankind. The diffu- 
sion of Buddhism in the context of a long-established Chinese culture would not have been possible had it not adjusted itself to the Chinese milieu by assimilating Confucian moral values and Taoist ideas, and employed a terminology familiar to Chinese disciples.

The translation of Buddhist literature from Pali and Sanskrit into Chinese proved to be a formidable undertaking, given the immensity of the collection of Buddhist classics, which contained a millenium of intellectual endeavor. The Buddhism brought to China initially encompassed both the old Theravada (Shravakayana) and the new Mahayana sets. An Shi-gao translated some of the first works in the late East Han Dynasty (25-220) and the effort lasted into the late Song Dynasty (960-1279). About 60 monks from the West accomplished much of the translation over the first three centuries in this period, while later works are credited to nearly one hundred Chinese monks who had been to the West for education in the Buddhist tenets. For the purposes of discussion, we can view this period in four stages: (1) The pioneering stage, from the mid East $\mathrm{H}$ an Dynasty (ca 150) to the West Jin Dynasty (265-420); (2) The development stage, from the East Jin Dynasty (317-420) to the Sui Dynasty (581-618); (3) The mature stage of the Tang Dynasty (618-907); and (4) The concluding stage of the Northern Song Dynasty (960-1127).

\subsubsection{The pioneering stage}

Indian civilization differed from Chinese civilization in many ways. For one thing, the diffusion of knowledge in ancient India was accomplished by word-of-mouth for quite a long period of time before written modes of communication were adopted. The Buddhist canon therefore appeared mainly in the form of an oral tradition when it first came to China. The Chinese people, ignorant of the canon's history, imagined that the scriptures were the Buddha's sutras, recorded by disciples around the time of his death and stored in caves and libraries before they were discovered and taken to China. At first, the Chinese monks had little choice as to what to translate and what not. This was left to the foreign monks who often carried the scriptures in their memory. The translations therefore tended to be only part of a whole text.

An Shi-gao, crown prince of Parthia, was one of the monk-scholars to arrive in Luoyang, the translation center organized by foreign monks. An spent more than 20 years in China translating Buddhist classics. The scriptures he translated were concerned primarily with Dhyana, the practice of meditation, and are recognized as conveying the import of the original thanks to his mastery of the Chinese language. According to A Comprehensive Catalogue of Sutras compiled by Dao An in the Jin Dynasty, An translated more than 41 volumes of Buddhist scriptures (Ma Zuyi 1984: 17).

Another notable monk translator toward the end of the third century was Dharmaraksa, who was of Rouzhi origin, but was born in Dunhuang in China. Proficient in both the Chinese and Indian languages, he translated over $100 \mathrm{M}$ ahayana texts. He would often dictate the text from memory for his Chinese scribes to put down in Chinese characters. His remarkable contribution was the Lotus Sutras, called in Sanskrit the Saddharmapundarika, a dissertation of great importance to the development of Mahayana. He also rendered the 25,000-line Perfection of Wisdom, which was the earliest of the Prajna Sutras, a substantial section of the M ahayana literature. 
He played an instrumental role in the spread of Buddhism in China through his translations and religious activities. During the 4th century, many monks fled to Dunhuang to escape the political and military tumult in northern China, and their literary and religious activities at this sanctuary further enhanced Dunhuang's fame as a Buddhist center (Editorial board 1988).

\subsubsection{The development stage}

The translation of Buddhist scriptures continued throughout the 4th century. The Imperial Court patronized Buddhist monks by offering grants for translation projects, and by overseeing the spread of Buddhist teachings. Sovereigns did this for merit and consecration, as well as to please the believing multitudes. Realizing the usefulness of the Buddhist canon, the Imperial Court exercised its prerogative by making the final decision about which translations were fit for inclusion in the canon. Such decisions were made, of course, on the advice of the experts. But it was with the Court's imprimatur that a particular collection of books was officially made the Buddhist canon.

And the translators certainly did not accomplish the project all by themselves, but worked with their peers. Such an arduous task called for men of genius. One such man was the eminent monk Dao An. Dao An was born in Hebei Province, and he left home to become a novice of Buddhism when still a boy. He was urged by his teacher to travel and study under some more knowledgeable monks. In 365, Dao An went to Xiangyang (in today's Hubei Province) and remained there for 15 years to spread Buddhism. He established his reputation by arranging the sutras in their proper order, compiling a catalogue of the Buddhist collection, writing commentaries, constructing stupas, and erecting statues. An important part of his work consisted of textual criticism of translations and terminology, and commentaries to explicate the essence of passages. The earlier translators often made mistakes, as some of them were not familiar with the implications of the original texts. Since the foreign monks often did not know Chinese very well, and their Chinese collaborators were ignorant of the foreign tongue, misinterpretations abounded. The difficulties encountered in translating were made worse, according to Dao An, by the very complex syntax and nuances of meaning of the foreign language. Very often, elliptical expressions would occur in the original text, and when a passage containing too many of these ellipses was rendered into Chinese, the resulting version could hardly be understood. Secondly, the foreign terminology was at times vague and ambiguous, and it was difficult to find the right turn of phrase in Chinese to convey the fine shades of meaning. In the third place, the involved, complicated sentences in some sutras might have appeared repetitious, but in reality they contained well-developed ideas which were lost in the process of translation. Finally, according to Dao An, the syntax of the foreign language was often the reverse of the Chinese, forcing the translator to straighten out the word order in the Chinese translation before the meaning of the sentence would become comprehensible. Dao An was well-read, and could discern the subtleties of these troublesome passages, and clarify their meanings through his explications, much to the admiration of Kumarajiva.

Moreover, Dao An made an attempt to collect as many of the sutras as possible. Wherever he went on his travels, he had sutras copied for him, or received compli- 
mentary copies from his Buddhist friends. This search for sutras made it possible for him to compile A Comprehensive Catalogue of the Sutras, a bibliography of all translations done from the Han Dynasty (25-211) to 374, the first of its kind in the history of Chinese Buddhism. He examined every piece of the sutras himself. His main problem was finding out the names of the translators, for the ancient copyists often neglected to include this information in the translation.

In 379 Dao An was abducted to Chang-an, where he spent the last few years of his life. Dao An was instrumental in getting the Sarvastivadin literature translated into Chinese. It was at this time that monks from Kashmir began to enter China in large numbers and they brought the texts of the dominant Sarvastivadin School of their homeland, which they then translated into Chinese, making Chang-an one of the important translation centers of the time. To carry on his intensive translation activities in Chang-an, Dao An assembled people to assist the foreign monks, providing a pool of trained talent in the city that was to prove extremely valuable and useful to Kumarajiva when the latter began his own translations (Lu Zheng 1979; M a Zuyi 1984: 29-33).

Kumarajiva was one of the greatest monk translators in Chinese history. Born in Kucha (Central Asia), he was trained in Afghanistan in both Theravada and Mahayana classics. Kumarajiva's fame as a scriptural scholar reached the northern Chinese Court (the country was then politically divided), and in 385 the ruler "kidnapped" him and brought him to Liangzhou in Sichuan Province, where he would stay for 15 years and improve his Chinese. Kumarajiva was brought by Yao Xing (366-416) who was ruling North China then, to Chang-an, a center bustling with Buddhist activities, where he was bestowed the title of national preceptor, and was surrounded by 1,000 monks and secular people (including some of the best scholars in the country) in daily work sessions. $\mathrm{H}$ is task was to retranslate the most influential of the Mahayana scriptures and produce definitive editions with authoritative interpretations. Until his death around 409, Kumarajiva and his collaborators produced a series of translations, including not only scriptures but also commentaries that helped to explain the primary texts. Their output included the Amitabha Sutra, basic text of the Pure Land school in China (402), the Perfection of Wisdom in 25,000 lines (404), the Treatise on the Great Perfection of Wisdom (405), and the two important M ahayana scriptures, the Lotus of the Good Law and the Sutra Spoken by Vimalakirti (406), among others.

Contemporaneous with or prior to Kumarajiva, translators had attempted to employ words and concepts derived from the Taoist texts in order to make the Buddhist scriptures more comprehensible as well as more acceptable to Chinese audiences- this was the method called GeYi (matching of meanings). But it did not always accurately communicate the contents of the original texts, and sometimes even distorted them. Dao An was opposed to this method and Kumarajiva rejected it altogether; the latter tried his best to create new proper names for rendering Buddhist concepts so that his translations were different from those of others and more faithful to the originals (Ma Zuyi 1984: 35).

But both Dao An and Kumarajiva were foreign monks. The first important monk translator not from the West was Fa Xian, who left China for India during Yao Xing's reign in 400 in search of Dharma or the Holy Law. After him a considerable number of Chinese monks participated in the pilgrimage. Some of them searched for the 
sacred texts, while others looked for famous Indian masters and invited them to come to China to practice the religion and teach Dharma. Fa Xian studied in India for quite a long period of time, and returned to China in 411 with packs of sacred scriptures, including the original version of the Vinaya (The Rules of Discipline), which had not been translated into Chinese at that time. He devoted the rest of his life to the task of translating the sutras he had brought back. To his credit are translations of the Mahaparinirvanasutra, the Vinaya of the Mahasanghika School, and his own book entitled Record of Buddhist Kingdoms.

\subsubsection{The mature stage}

The Tang Dynasty saw a boom of Buddhism and translation of the Buddhist literature. Translation during this stage was characterized by (1) the appearance of more Chinese monk-translators proficient in both Chinese and Sanskrit, and conversant with the Buddhist tenets; (2) the translation of entire works instead of just excerpts; (3) support from the Court; and (4) better management of the translation project.

In this flourishing period of translation, H suan-tsang was the most eminent of all the learned monks. He became interested in Indian Buddhist philosophy when he was still very young, and he left the country in 629 for the West in search of answers to the problems that bothered him. After a sixteen-year stay as a devoted pilgrim in the West, he returned to Chang-an, the Tang capital, bringing back with him hundreds of pieces of sutras. He remained there for nineteen years, translating the classics. He took care to translate entire works, rather than being content with excerpted translations. Thanks to him, the corpus of M ahayana scriptures was made available, as well as its most important treatises and commentaries. In the 19 years preceding his death, he completed the translation of 75 works, amounting to 1,335 volumes, which is more than half the total translations of Buddhist scriptures done in the Tang Dynasty (Lu Zheng 1979). ${ }^{2}$ H suan-tsang also wrote Da Tang Xi Yu Ji (Records of the Western Regions under the Reign of the Great Tang), a work of great value to historians and archeologists since.

\subsubsection{The concluding stage}

By the conclusion of the third stage, which spanned the 2nd century to the mid 9th century, almost all the important Buddhist scriptures had been translated into Chinese. The Chinese Buddhists began to sort through the quantities of translated scriptures and reflect on the profundity of the doctrines. They gradually lost interest in translation itself. The rulers of the late Tang Dynasty did not support translation because of social considerations, with the result that few scriptures where translated for nearly 100 years until Zhao Kuang-yin (927-976), the first emperor of the Song Dynasty assumed the throne in 960 . The emperor, being a pious believer in Buddhism himself, decreed that a translation academy be set up for rendering the sutras of late Indian Buddhism. Translation boomed again for about 100 years, and some 758 volumes of scriptures were translated (according to Lu Zheng's Buddhism in the Song Dynasty, cf. Ma Zuyi 1984: 69-70), but no translators like Fa Xian or H suantsang emerged and no significant Buddhist scriptures were translated. 


\subsection{Methods and Theories of Translation}

In the early stage, translating often involved several monks collaborating on a work. Some foreign monks attempted the translation themselves, but more often they solicited the assistance of the Chinese. Often, a foreign monk would explain the text in Chinese, and the Chinese collaborator would write down what he heard. This was the prevailing technique employed during the $3 r d$ and 4th centuries, though it would appear somewhat inadequate by later standards. By the late 4th century, the Chinese monks had become competent enough to handle translation without help from foreign monks. Towards the end of the 4th century when preparations were being made for the translation of theSarvastivadin canon, Dao An began to bring monks together to form a translation workshop. With the arrival of Kumarajiva in 401, the translation workshop was sanctioned by the Court to carry out large-scale translations.

From the outset translators of Buddhist literature were confronted with the problem of translating the form of the sutras, including the names and terms. At first, An Shi-gao, Zhi-chen (active between 178 and 189), and other early translators favoured literal translations which were faithful to the form of the original. Later on in the first stage, Zhi Qian (active between 223 and 253) insisted on translating the content of the sutras in elegant and readable style, sometimes at the expense of accuracy. But his emphasis on style came under attack from Seng Rui (d. 67), one of the followers of Kumarajiva, who asserted that the elegance of Zhi Qian's translations clouded the main ideas of the passages.

Later in the second stage of Buddhist translation, Dao An gave more serious consideration to the form and style of translations. Though not proficient in Sanskrit, Dao An was familiar with Buddhist doctrines, and as a result his commentaries on the sutras were commended even by Kumarajiiva. Dao An felt that one of the greatest weaknesses of free translation, translating only the meaning of the sutra, was that translators would often allow their own ideas to get mixed in with those of the original text, so that the translations were often influenced by non-Buddhist concepts. Dao An therefore advocated that the translator follow the original text as closely as possible. In his opinion there were five ways in which translators might deviate from the original. Called "wu shi ben" (or "five cases in which the meaning of the original was lost"), these were: (1) reversing the syntactic order of the original so as to conform to Chinese speech habits; (2) attracting the attention of Chinese readers with a polished, literary style instead of the unadorned style of the original; (3) omitting repetitions, chanted verses, and exclamatory phrases; (4) occasionally omitting lengthy explanations and commentaries found in the middle of a passage; and (5) ignoring a paragraph repeating a preceding passage.

Dao An believed that, when translating Buddhist scriptures, translators should strive for faithfulness to the original, but also make the original's profound truths understandable to the laity of the age. This was a first difficult task. The difference between the wisdom of Buddha and the ignorance of the common people was vast, so it was no easy matter to make the subtle remarks of a sage who had lived 1,000 years before understandable. There was also the problem that with the passage of over 1,000 years since the Buddha's death, it was hard to verify the truth of Buddha's teaching. These problems were Dao An's famous "san bu yi" (three difficulties) (Ma Zuyi 1984: 31-33; Kenneth Chen 1972: 369-370). 
Kumarajiva felt that translations could never capture the flavour of the original; it was like feeding someone with food that had been chewn by someone else- not only was the taste lost, but it might even cause nausea. Kumarajiva was not in favour of faithful adherence to the original, as was Dao An; instead, he advocated a process of selecting and shortening the texts and was interested only in retaining the meaning of the original. For him the main goal of the translation was to get at the central theme of the sutra. Although he did not follow the original literally, he was technically extremely careful not to let errors occur in his translation, making textual emendations and collations whenever the occasion demanded. At times, however, he would take the liberty of substituting, for the benefit of the reader, a better known proper name for one that was not so familiar.

Take the translation of the Lotus Sutra, for example. The Sanskrit text was rendered literally into Chinese by Dharmaraksha in his version called "Tian jian ren, ren jian tian" (The Heaven sees the man, the man sees the Heaven). When Kumarajiva came to this passage, he claimed that its meaning was in accord with the original but that its expression was excessively plain and even uncouth. Seng Rui promptly suggested changing the sentence into "Ren tian jiao jie, liang de xiang jian" ( $M$ an and the Heaven met and were able to see each other), a solution Kumarajiva approved of ( $\mathrm{Ma}$ Zuyi 1984: 34-35; Kenneth Chen 1972: 371). With regard to form, the principles advocated by Kumarajiva eventually ruled on account of his authority and prestige.

As regards the problem of translating or transliterating foreign proper names, Hsuan-tsang proposed that five categories of terms be left untranslated ("wu bu fan"): (1) terms having to do with esoteric concepts, such as dharani or mandala; (2) terms pregnant with meaning, such as Bo Jia Fan for bhagavan; (3) things which do not exist in China, such as the Jambudvipa tree; (4) extant terms used by ancient translators, such as Anuttara-samyak-sambodhi; and (5) elevated terms, such as Prajnaparamita (Ma Zuyi 1984: 58-60; Kenneth Chen 1972: 372).

\subsection{Significance of the Translation of Buddhist Scriptures}

As discussed in the above, the encounter of Chinese and foreign cultures began with the diffusion of Indian Buddhism in China. The translation of Buddhist classics lasted over 1,000 years, exerting a far-reaching influence upon Chinese culture in the fields of philosophy, religion, literature, phonology, language and linguistics, music and dancing, painting and sculpture. During this period, countless people participated in the translation of Buddhist scriptures, many of whom were masters. A large number of sutras were translated. During the period from the Han Dynasty to the early Tang Dynasty alone, 3,616 sutras were translated into Chinese, amounting to 8,641 volumes. According to $\mathrm{Hu}$ Shi (1929-1986), more than 15,000 volumes of translated Buddhist scriptures were produced over a period of 100 years.

Apart from the discussion of the significance of the sutra translations in ancient China, there are some further points that need to be considered. First, the translation of Buddhist scriptures underwent three stages of development with respect to those engaged in the process of translating. In the initial period, translations were done by foreign monks; then Chinese and foreign translators worked in tandem, and finally Chinese translators took over the job of translating. This transition indicated a shift from passive to active acceptance of foreign cultures on the part of the Chinese people in general and the Buddhist believers in particular. 
Secondly, the translation of Buddhist scriptures was a big project, demanding collaboration among translators and a division of labour. During the mature stage of translation, teams of translators were organized as follows: (1) chief of translation (译主); (2) translator who recited the foreign text and translated it into Chinese (度语); (3) verifier of the meaning in the Sanskrit text (证梵); (4) scribe who wrote the translation down in Chinese (笔受); (5) verifier of the meaning of the written Chinese (证义); (6) polisher of style (润文); (7) proofreader (参译); and (8) corrector of the Chinese characters (刊定). This well-organized team of translators easily matched the Arab Translation Academy at Baghdad or the Translation Academy at Toledo, Spain.

Thirdly, as time went on many remarks or opinions on the translation were recorded, the earliest example of which was by Zhi Qian in his "Preface to Dharmapade," a foreshadow of Yan Fu's Three-Character Criteria of translation, viz. faithfulness, expressiveness and elegance. ${ }^{3}$ Dao An's translation principles advocated "faithful translation" and wu shi ben, san bu yi, which were observed by later translators. Kumarajiva put forth the idea of "aiming at the expressiveness of the original," the flow of the translation should be based on the original. These translation theories guided the translation work of the time and enriched Chinese translation theory.

Fourthly, the translation of Buddhist scriptures developed from immature literal translation to immature free translation, then from comparatively mature literal translation to more mature free translation, and finally to an integral practice of both literal and free translations. Theoretical justification of literal and free translations by modern theorists can be traced back to the rule-of-thumb experiences of these early masters of translation.

Fifthly, the translation of Buddhist scriptures was conducive to the growth of the Chinese language. Lexically, some 35,000 new words found their way into the Chinese word-stock; phonologically, the practice of translating Buddhist scriptures sensitized the ears of the Chinese to the tonal qualities of individual Chinese character-words, and a four-tone scheme was devised as a result, which made poetic composition much easier. Liang Qichao (1932-1990) pointed out 10 great changes in syntax and style that evolved over the centuries, such as the increased number of inverted sentences.

Sixthly, the Buddhist classics are of great literary value, and the translation of these classic works enriched Chinese literature with new motifs, imagery, and techniques. They prompted the rhymed poetry of the Tang Dynasty and the mystery and ghost stories of the Six Dynasties. Romantic literature appeared and great literature flourished thenceforth.

\section{TRANSLATION \& THE SPREAD OF CHRISTIANITY \& SCIENCE IN THE LATE MING \& EARLY QING DYNASTIES}

The discovery of theAmerican continent by Christopher Columbus in 1492, Vasco de Gama's maiden voyage around the Cape of Good Hope to India in 1498, and Ferdinand Magellan's sail around the globe in 1522 enticed the European colonial adventurers into attempting to conquer other parts of the world. The emergence of capitalism in Europe prepared material conditions for the growth of the natural sciences. Francis Bacon (1561-1627) of England, Galileo (1564-1642) of Italy, and 
Johann Kepler (1571-1630) of Germany were among the illustrious scientists of the time. Roman Catholicism was trying to expand its ecclesiastical domain to the O rient and the mid-16th century saw Jesuit missionaries traveling to China in the wake of the Western colonial adventurers with the intention of converting the Chinese to Christianity while, at the same time, bringing them science and technology.

\subsection{The Jesuit Missionaries}

The arrival of Italian missionary Michael Ruggieri (1543-1607) on the shores of Canton in 1580 marked the beginning of the second wave of translation activity. Now, the texts were not from the West that was India, but the West that was Europe; and the works translated were no longer of Buddhist themes, but of Christian and scientific matters. From the reign of Wan Li (1573-1619) of the late M ing Dynasty to the reign of Kang Xi (1662-1722) of the early Qing Dynasty, missionaries from Italy, Spain, Portugal, France, Switzerland, Germany, Belgium, and Poland arrived in China to spread their religion. More than 70 of them are recorded in history. Most of these missionaries had their works or translations published in China, and of the more than 300 works in total, 120 concerned science and technology. The most prominent missionaries were M atteo Ricci (1552-1610), Jean Adam Schall von Bell (1519-1666), Jacobus Rho (1593-1638), and Ferdinand Verbiest (1623-1688); the 75 works produced by these four missionaries touched such areas as astronomy, mathematics, physics, cartography, medicine, religion, and linguistics.

\subsection{Translators-Turned-Scientists}

Among the Chinese collaborators who worked with these foreign missionaries in scientific and technical translations were Xu Guangqi (1562-1633), Li Zhizao (15651630), Li Tianjing (1579-1659), Wang Zheng (1571-1644), all of whom were either holders of the Jin Shi degree, or had successfully passed the imperial examinations. Xu Guangqi, a high-ranking official and a versatile scientist of the late M ing Dynasty, had played an active part in importing Western science into China at a time when traditional scholars disdained science. When Xu was in charge of the Hanlin Academy in Beijing, the top academic institution in China, he worked in close collaboration with M atteo Ricci on the translation of the 13 volumes of Euclidean plane geometry, though only six volumes were actually translated. It was not until 200 years later that Li Shanlan (1811-1882) took up the job of translating the remaining volumes with the help of Alexander Wylie, a British Protestant missionary. M any of the terms Xu used are still in use today. Xu was also enthusiastic about introducing Western methods of farming to China. Working with Sabbathinus de Ursis (1575-1620), an Italian missionary, he translated a six-volume work on water conservation and irrigation methods in the West. His method of translating was selective, in that he included only those methods he thought practical and applicable to Chinese conditions; he also conducted experiments in order to find out if the methods were really useful. Another enormous project Xu undertook was the revision of China's Almanac during the reign of Chong Zhen (1628-1644). He enlisted Li Zhizao (1565-1630), Nicolaus Longobardi (1559-1654), Jean Terrenz (1576-1630), and later Johann Adam Schall von Bell and Jacques Rho, to help with the 130-volume project, historically known as 
the Almanac: Chong Zhen Reign. It was not exactly a translation of the Western almanac, but an adapted version meant to fit Chinese practice. Although advanced in age, Xu Guangqi insisted on verifying the accuracy of the new almanac himself.

China had been a feudalistic country for more than two millenia when the Western missionaries arrived. Chinese officials and the intelligentsia had grown accustomed to doing things conservatively, and were content with the status quo. They often looked upon Western ideas with skepticism, or resisted them altogether. The contributions of Xu Guangqi and of other contemporary or later scholars were thus extraordinary. They not only helped bring in new tools and practices, but also new ways of looking at the world and at China herself. Xu's reasons for learning from the West were explicit: "To excel the Western countries, we must learn and know things of and about the West; to do so, we must translate works written by Western authors." (See "Preface to the Almanac", Xu Guang Qi's Works, volume 8, p. 374.) They studied the strong points of Western countries in order to overcome China's own weaknesses, and in the process, also identified shortcomings in Western practices and tried to supplement them with Chinese knowledge.

But the work of Xu Guangqi and others did not have a widespread and lasting influence on Chinese society-they faced enormous opposition from the old guard of their time, but also took no specific steps to disseminate the knowledge they had gained from Western missionaries. This would only take place in the second half of the 19th century when China was forced to open her doors to the Western powers, and the third wave of translation occured.

\section{ENGLISH EDUCATION AND TRANSLATION IN THE MID-19TH CENTURY}

\subsection{English Education in the Early Days}

Robert Morrison (1782-1834) was the first British Protestant missionary chosen to come to China to spread Christianity. He came to China via the United States, arriving at Macao on September 4, 1807, before proceeding to Canton, where he began to learn Cantonese and Mandarin. Between 1808 and 1813, Morrison translated the New Testament and, in collaboration with William Milne, completed the translation of the Old Testament between 1814 and 1819. In 1823, both books of the Bible were published in M alacca in 21 thread-bound volumes under the Chinese title Shen Tian Sheng Shu or Holy Book of the Divine Heaven. The publication of the Chinese version of the $\mathrm{H}$ oly Bible was of monumental importance to the cultural exchange between China and the West in the 19th century. To give just one example, the translated Bible had a big impact on the thinking of Hong Xiuquan (1814-1864), leader of the Heavenly Kingdom Movement (Xiong Yuezhi 1994: 95-99). M orrison's role as a cultural envoy also worked both ways: he translated Chinese classics for Western readers, such as the Analects of Confucius (1809) and the Three Character Aphorisms (1802). M orrison's Dictionary of the Chinese Language, a two-way bilingual dictionary running over 2,500 pages, was published in 1823. It was of great help to language learners and translators (Xiong Yuezhi 1994: 97-100).

In November 1818, Morrison founded the Anglo-Chinese College (Ying Hua Shu Yuan) in M alacca. The college taught primary and secondary students languages, 
literature and science. Yuan Dehui (ca. 1800-?) studied at the College between 1823 and 1827. For several years he worked as a translator for the Li Fan Yuan (M inistry of Foreign Affairs), and in 1839 he became Lin Zexu's assistant in charge of foreign affairs. Robert M orrison's importance was commemorated by the M orrison School of Macao, set up 1839; it moved to Hong Kong in 1843 but was closed in 1850 due to lack of funding. However, following the signing of the First Treaty of Nanking between China and Britain in 1842, many other missionary schools began operating in the coastal cities opened up to the Western countries. Yung Wing (1828-1912) was one of the youngsters who graduated from the M orrison School and later went to the United States for further education, becoming the first Chinese to graduate from Yale with a baccalaureate. Yung Wing played his part in promoting understanding between the U.S. and China, persuading the Qing court to send young people to the U.S. to study Western science and technology (Xiong Yuezhi 1994: 122-129). According to one estimate, some 200,000 students were registered in missionary schools in 1912 when the last emperor of the Qing Dynasty was dethroned, and many more students had benefited from missionary education over the past half century or so. Dr. Sun Yat-sen (1866-1925), Soong Chingling (Madame Sun 1893-1981) and Yung Wing were just a few of the many notable Chinese to come out of these schools and dedicate their lives to the wellbeing of the Chinese nation.

Another contribution made by the missionaries was the establishment of publishing houses. The first was set up in Malacca in the early 19th century, where it introduced movable lead type. M ohai Shu Guan (London M issionary Society Press) was set up in Shanghai in the mid-19th century, and remained active for at least two decades, during which time it published translations dealing with both scientific and religious subject matter; the publication of these works had a great influence on the intellectual worlds of both China and Japan (Xiong Yuezhi 1994: 213-214).

\subsection{Training Translators}

From the signing of the First Treaty of Nanking in 1842 until the signing of the Treaty of Tientsin in 1858, there were many misunderstandings between Westerners and the Chinese in their official interaction as a result of different interpretations of certain clauses of treaties or conventions. ${ }^{4}$ Deciding which text should be taken as authentic became a problem for the negotiators. Article $L$ of the Treaty of Tientsin (1858) stipulated that

All official communications addressed by the Diplomatic and Consular Agents of $\mathrm{Her}$ Majesty the Queen to the Chinese Authorities shall, henceforth, be written in English. They will for the present be accompanied by a Chinese version, but, it is understood that, in the event of there being any difference of meaning between the English and the Chinese text, the English Government will hold the sense as expressed in the English text to be the correct sense. This provision is to apply to the Treaty now negotiated, the Chinese text of which has been carefully corrected by the English original. (1917, vol. 1: 418)

However, the Chinese text of Article $L$ read somewhat differently, saying that

Henceforth the communication shall be written in English; but until China has selected students for learning the English language and their English has become very fluent, the 
communication shall still be accompanied with a parallel text in Chinese..." (Ditto; Fan's back translation)

There is no way of telling how this statement found its way into the Chinese text. But the fact was that China had been forced to open its doors to the Western world, and learning Western languages had become a matter of necessity. The negotiators probably decided the statement should be included in the Chinese text in order to force the Emperor to start a language school for training interpreters. Yi Xin (?-1898), the official in charge of foreign affairs, and two other officials presented a memorandum to the Emperor, asking for permission to run a language school.

The school, named Tong Wen Guan, was officially opened on June 11, 1862, with J. S. Burdon (1826-1907), an English Protestant missionary, hired as the first English instructor. Some 54 foreigners were employed as instructors in English, French, German, Japanese, chemistry, astronomy and medicine, as well as 32 Chinese instructors in Chinese and mathematics (Xiong Yuezhi 1994: 310-312). There were three main channels of enrollment: some students were recommended by the eight $M$ anchurian banners, and did not undergo exams; others were young men of different nationalities who already had a academic degree of one kind or other; the rest were excellent students from Shanghai and Canton who did not have to take exams. From 1866 on, many of Tong Wen Guan's students began to serve as interpreters, accompanying Robert H art and Anson Burlingame on trips abroad. In 1876, when China had established its first embassies, these students were employed as staff members of diplomatic missions (Xiong Yuezhi 1994: 316-317).

Unlike the translation courses conducted in tertiary institutions today, which are designed to teach students virtual skills, the Tong Wen Guan students were required to translate actual foreign works, which were later used as their own textbooks; at the time there were no existing textbooks for the Chinese students to use. The foreign instructors acted as editors of these works. Some 25 works were translated by instructors and students of Tong Wen Guan, including Wheaton's Elements of International Law, Code Napoleon, Fawcett's Political Economy, Chemistry for Beginners, Elements of Astronomy, English Grammar, etc. (Xiong Yuezhi 1994: 322-323). Following Beijing's Tong Wen Guan, the Shanghai Tong Wen Guan was set up in 1863, and renamed Guang Fang Yan Guan in 1867. No longer a school for language students only, more science courses were incorporated into the curriculum, and the school became comprehensive in nature (Xiong Yuezhi 1994: 337-340).

The mid-19th century saw the establishment of government-run translation de partments, among them the Fan Yi Guan of Kiang-Nan Arsenal of Shanghai (1867), the Qiang Xue Shu Ju of Beijing (1895), the Yi Shu Ju of Beijing (1896), the Bian Yi Ju of Jing Shi Academy of Beijing (1901). At the turn of the century, three privatelyrun translation organizations came into being in Shanghai, including the Translation Section of the Commercial Press. Some of the organizations put out dailies, weeklies, bi-monthlies, and monthlies to publish translations of scientific and technical writings (Li Nanqiu 1981: 2; Luo Xinzhang 1984: 232-233).

The Fan Yi Guan (Translation Department) of Kiang-Nan Arsenal of Shanghai (1867) merits special mention. This translation department was set up to translate information concerning the manufacture of Western machinery. Zeng Guo-fan (1811-1872), the Provincial Governor, said in a memorandum to the Emperor that "Translation is essential for the project of manufacturing machines; [...] so that later 
we can write our own books without the help of Westerners" (Xiong Yuezhi 1994: 495). With John Fryer and Young Allen acting as both instructors and chief translators, the Department turned out many valuable works of translation that were later used as textbooks for other schools; many of its students were recruited as employees. The Translation Department laid out a set of rules for settling terminological problems: (1) use ready-made Chinese terms or consult businessmen and craftsmen for the commonly accepted usages; (2) create new terms, following Chinese rules of character formation; and (3) compile glossaries, listing both the English terms and their Chinese equivalents, especially newly coined terms. Many of the terms they created are still used today. From 1871 to 1909 roughly 160 works of translation were published by this Department (Xiong Yuezhi 1994: 499). Works translated included Homely Words to Aid Governance, International Law, Elements of Arithmetic, M ineralogy, The Medical Handbook, Manual of the Steam Engine, The Armies of the Great Powers, Naval Regulation, M ethod of Conducting a Trigonometrical Survey.

For most of the 19th century, translation of a Western work was not done by a single bilingual speaker but through the joint efforts of an English speaker and a Chinese collaborator, with the former explaining the contents and the latter writing down the ideas in readable Chinese. In due course, these Chinese collaborators learned a great deal from the works they had translated and become experts in those fields. Representative of this group of pioneers were Li Shanlan (1811-1882), a notable scientist who was later appointed instructor to Tong Wen Guan of the Jingshi Academy, and Wang Tao (1828-?), a resourceful translator and enthusiastic advocate of the new science (Xiong Yuezhi 1994: 266-276).

\subsection{Compilation of Textbooks}

New textbooks were first written by teachers in missionary schools in 19th century China. In 1877, the missionaries in China convened a meeting in Shanghai, where they decided to establish a committee for compiling textbooks. This was how the Yi Zhi Shu Hui, or The School and Textbook Series Committee was formed, with John Fryer and Calvin Mateer as chairmen. By 1890, 98 textbooks had been published. Chinese scholars also began to compile textbooks towards the end of the last century. The Commercial Press and the Civilization (Wen Ming) Press played an important role in producing these textbooks, which ranged from physics and chemistry to social sciences, and from accounting to foreign languages. It is not certain when the first textbook for translation courses was compiled and published. The Commercial Press Catalogue (1897-1949) lists six titles under "428.5 Translation," the earliest of which is The Translator's Assistant (1907) by K.S. Wu, one of the volumes for the Teaching Yourself English Series put out by the Commercial Press. A more textbook-like production was the two-volume Translation Exercises (1911) by U.B. Li, a collection of passages for translation practice that included tips for using certain expressions, but not much theory to speak of. No translation course books are recorded for Japanese, German, and French in this Catalogue.

A typical curriculum for a 12-year program of a Zhengjiang's Girls' M ethodist School at the beginning of the 20th century included English as one of the courses offered, starting from the third year (Xiong Yuezhi 1994: 298). We have no way of knowing how English was taught in the school, but we can assume with some degree 
of certainty that the grammar-translation method was used during the early days of English education in China. By 1929 when Ai Wei had his paper treating some aspects of translation published, the teaching of translation had al ready become a part of the curriculum as an independent course. Ai Wei made a statistical analysis of the scores of translation exercises done by senior high school students, comparing the percentages of those using the literal method of translating versus the free method. The degree of difficulty of the English original was about the same as the exercises used in most tertiary institutions today. Ai Wei concluded that translations using the free method were much better than those done with the literal method (Ai Wai 1929; see CTA \& Translation Bulletin 1984: 160-180). According to Fan's finding, some 21 works of translation practice, studies and references were published in the first half of the 20th century and can still be found in some libraries. Some of them were simple translation exercises, while others reached a relatively high level of scholarship. There might have been more works on translation studies and practice written and published but for the unsettled situation of war-torn China in the first half of the century. Scholarly studies on translation practice would only flourish in a more peaceful age yet to come.

\section{ACHIEVEMENTS: $1950-1997$}

\subsection{The Statistics: the Three Regions of China}

Shouyi Fan recently completed a bibliographical survey of the publication of works of translation studies, translation course-books and references over the past half century in China, including works issued in Taiwan and Hong Kong. The number of works published in the three regions of China are 457 (M ainland), 94 (Taiwan), and 83 (Hong Kong) respectively, totaling $634 .{ }^{5}$ The following table shows the progression of publication at five-year intervals over the past half century:

\begin{tabular}{lcrrrrrrrrrr}
\hline China & $\mathbf{5 0 - 5 5}$ & $\mathbf{5 6 - 6 0}$ & $\mathbf{6 1 - 6 5}$ & $\mathbf{6 6 - 7 0}$ & $\mathbf{7 1 - 7 5}$ & $\mathbf{7 6 - 8 0}$ & $\mathbf{8 1 - 8 5}$ & $\mathbf{8 6 - 9 0}$ & $\mathbf{9 1 - 9 5}$ & $\mathbf{9 6 -}$ & No Year \\
\hline Mainland & 4 & 13 & 4 & 1 & 2 & 20 & 94 & 118 & 128 & 73 & - \\
Taiwan & 2 & 2 & 2 & 7 & 14 & 13 & 16 & 14 & 14 & 4 & 6 \\
Hong Kong & - & 1 & 1 & 4 & 15 & 20 & 9 & 8 & 8 & 6 & 11 \\
Total & 6 & 16 & 7 & 12 & 31 & 53 & 119 & 140 & 150 & 83 & 17 \\
\hline
\end{tabular}

The following observations have been made, based on the table above:

During the first 16 years, some 21 works (relevant to translation from or into Russian, English and Japanese) were published on the Mainland; the most notable work of this period was the pioneering two-volume course-book for tertiary use entitled Translation: Its Principles and Technique by Lu Dianyang (1959). In the same period, eight works were put out in Hong Kong and Taiwan. However, during the next 10 years, between 1966 and 1975, when only three works were published on the Mainland, some 40 were produced in Taiwan and Hong Kong. Since 1976, scholars on the Mainland have been working with redoubled efforts, turning out more and more studies on translation as well as translation course-books of various kinds. 
It is apparent that the pace of translation studies and publishing of textbooks is closely linked to economic fluctuations in a given country or region; booms in translation teaching and translation studies have much to do with the intensity of economic activities and commercial exchanges with the rest of the world. In the early years of the People's Republic, especially in the mid-1950s, Chinese economic plans were heavily dependent on Soviet aid, which contributed to the dominance of Russian in Chinese foreign language education. However, top leaders of China saw the necessity of adding more foreign languages to the curricula at the tertiary level.

\subsection{Translation and Variety of Languages: Mainland China}

The following more detailed progression table adds a few more points to our observations of what has happened on the M ainland.

\begin{tabular}{lccccccccccc}
\hline & $50-55$ & $56-60$ & $61-65$ & $66-70$ & $71-75$ & $76-80$ & $81-85$ & $86-90$ & $91-95$ & $96-$ & Total \\
\hline English & 2 & 7 & 1 & - & 2 & 18 & 71 & 91 & 106 & 67 & 366 \\
Russian & 1 & 6 & 3 & 1 & - & - & 10 & 10 & 8 & - & 37 \\
Japanese & 1 & - & - & - & - & 1 & 10 & 8 & 8 & 2 & 30 \\
French & - & - & - & - & - & - & 3 & 1 & 1 & 1 & 6 \\
German & - & - & - & - & - & 1 & - & 4 & - & 2 & 7 \\
Spanish & - & - & - & - & - & - & - & 3 & - & - & 3 \\
Arabic & - & - & - & - & - & - & - & 1 & 3 & - & 4 \\
Others & - & - & - & - & - & - & - & - & 2 & 1 & 3 \\
Total & 4 & 13 & 4 & 1 & 2 & 20 & 94 & 118 & 128 & 73 & 457 \\
\hline
\end{tabular}

With the conclusion of the Cultural Revolution, there were renewed efforts at writing and publishing works of translation study and practice. Between 1976 and 1980, 18 English works, one Japanese work (sci-tech translation), and one German work (sci-tech translation) were put out. Of the 18 English-related works, 10 were concerned with discourses on the practice of general translation, four with sci-tech translation, two with medical translation and two with oral interpretation. There were already signs that production of works on English-related sci-tech translation was on the rise. Sure enough, between 1981 and 1985 there were 18 works on sci-tech translation published to meet the demand for the translation of sci-tech education materials. This trend continued into the next four year interval, with 14 works appearing in print. Between 1991 and the present, 12 more works on sci-tech translation have come off the presses. Over the past 20 years, eight out of 28 Russian-related works, nine out of 29 Japanese-related works, and four out of seven German-related works have been about sci-tech translation. This state of affairs demonstrates that China has been focusing her attention chiefly on advances in science and technology in countries like the USA, the UK, Canada, Russia, Japan and Germany.

The publication of four Arabic-Chinese translation course-books between 1987 and 1995 indicates China's increased contacts with the Arabic world. The only Korean-Chinese translation course-book (1992) is the outcome of China's growing 
concern with the Korean Peninsula. To the best of our knowledge, many translation course-books related to other minor languages have been used in some tertiary institutions. These manuscripts have not yet been formally published because of a lack of sponsorship. Some far-sighted entrepreneurs are expected to give financial support for their publication.

Most of the works dealing with non-English and Chinese translation focus on practical translation skill rather than theory, except for a few scholars of Russian whose works touch on theories of translation, like Cao Wenxue's On Translation (1994). In this respect, English-speaking scholars have contributed much more to the growth of theoretical studies of translation.

Works dealing with professional translation studies and practice have been published in areas such as agriculture, geology, medicine, machinery, finance and accounting, trade and economics. H owever, other fields remain untouched, waiting for scholars to plow and plant; these encompass such areas as diplomacy and national defense, communications and transportation, government and law, film, television and drama, tourism and history, computers and telecommunication, light and heavy industries, etc. Valuable papers have already been presented on these subjects and have been expanded into book-length works for the benefit of specialized students.

\subsection{Theoretical Works of Translation: Mainland}

Works of translation theory include Zhang Jin's Principles of Literary Translation (1987), Jin Di's On Equal Effect Translation (1989), Liu Miqing's Studies on Translation Today (1990), Wu Xinxiang and Li Hongan's Explorations in Equal Value Translation (1990), Xi Yongji's A Comparative Study of Translation Aesthetics (1992), Fu Zhongxuan's The Practical Translation Aesthetics (1993), Dan Shen's Literary Stylistics and Fictional Translation (1995), Liu Miqing's Introduction to Translation Aesthetics (1995), Cai Xinle and Yu Dongzhan's Literary Translation Theory: A Hermeneutic Approach (1997), etc. Translation historians have produced works like A History of Translated Literature in China (Chen Yugang 1989), A H istory of Translation Studies in China (Chen Fukang 1992). A Short H istory of Translation in China (Prior to M ay 4th M ovement) (Ma Zuyi 1984), TheH istory of Science Document Translation in China ( $\mathrm{Li}$ Nanqiu 1993), 1949-1966: On Translations of British and American Literatures of the PRC (Sun Zhili 1996), A Short History of Translation in the West (Tan Zaixi 1991).

\subsection{Taiwan and Hong Kong's Contributions}

Scholars from Taiwan and Hong Kong have produced many works worthy of emulation by Mainlanders. For example, the translation of English news (Wang Jia-shi and Huang San-yi 1969; Li Chien-ying 1983); the history of the translation of Buddhist classics (Pei Yuan 1983; Wang Wen-yan 1984; Hsuan Chien-jen 1986/1996; Chao Wei-pen 1993; Chang Man-tao?), a glossary of translation terms (Chan Sin-wai 1993), a text on legal translation (Yu Wen-ching 1976), and many very handy translation manuals (Fang Le-tien 1957; Phillip Sun and Serena Fung (Jin) 1977; Luo Si 1979; Simon S. C. Chau 1980; Hu Tsi-tan 1980). Some M ainlanders (Huang Kai 1991; Liu Miqing 1993; 1995) have had their works published in Hong Kong and Taiwan in recent years, sharing their expertise with their counterparts in these two regions. The 
Hong Kong Conference on Translation Teaching, (December 2-4, 1997) signalled the beginning of more frequent exchanges of information and closer collaboration. The 21st century shall see even greater achievements in the three regions of China.

\section{NOTES}

1. See Shouyi Fan's article on "Translation of English Fiction and Drama in Modern China: Social Context, Literary Trends, and Impact" in this issue.

2. According to Gernet (1986: 279), H suan-tsang was responsible for about a quarter of all the translations of Indian texts into Chinese, about 1,338 chapters out of a total of 5,084 chapters translated in six centuries by 185 teams of translators.

3. See Shouyi Fan, "Ever Since Yan Fu and His Criteria of Translation," in Translation: Theory and Practice- Tension and Interdependence, ATA Scholarly Monograph, Series V, New York, SU NY, 1991.

4. See Shouyi Fan's "A Linguistic Study of 'Treaty of Nanking' and 'Treaty of Wang-Hea',' Journal of Foreign Affairs College, 1992, pp. 54-62

5. If weinclude the 21 titles published in the first half of the 20th century, and four works from M acao and two from Singapore, the total number of titles adds up to 654. Thanks are due to Mu Lei, Simon Chau, Zhang M eifang, who have added more titles to my collection; and a special thank-you goes to Serena Jin whose prompt arrangement with the Library of Hong Kong Chinese University made it possiblefor Fan to check and find titles he had missed in the previous version of his paper, presented on December 2, 1997 at the Hong Kong Conference on Translation Teaching.

\section{REFERENCES}

Cai, Xinle, and Dongzhan Yu (1997): Literary Translation Theory: A Hermeneutic Approach, Kaifeng, University of Henan Press.

Cao, Wenxue (1994): Translation, Changchun, Kirin Literature and History Publishing House.

Chao, Wei-pen (1993): I Ching Su Yuan: H sien Tai Wu Ta Cheng Wen Sheng Ching Fan I Shih, Hong Kong, China Religion Studies Institute.

Chan, Sin-wai (1993): A Glossary of Translation Terms, English-Chinese, Chinese-English, Hong Kong, The Hong Kong Chinese University.

Chang M an-tao (?): A History of Translation of Buddhist Classics, Taibei, The Ta Sheng Publishing Co.

Chau, Simon (1980): ECCE Translator's Manual-An Annotated Bibliographical Handbook on English-Chinese, Chinese English Translation, with J. J. Deeney, Hong Kong, Extra-mural Department, the Chinese University of Hong Kong.

Chen, Fukang (1992): A History of Translation Studies in China, Shanghai, Shanghai Foreign Languages Education Publishing House.

Chen, Kenneth (1972): Budddhism in China, Princeton (NJ), Princeton University Press.

Chen, Yugang (1989): A History of Translated Literature in China, Beijing, China Translation and Publishing Corporation.

Chien, Po-tsan, Sh ao, H sun-cheng and Hua Hu (1964): Concise History of China, Beijing, Foreign Language Press.

Commercial Press (1981): The Commercial Press Catalog (1897-1949), Beijing, The Commercial Press.

CTA \& Translation Bulletin (1984): Collected Essays on Translation Studies, Beijing, Foreign Languages Teaching and Research Press.

Editorial Board (1988): Journal of Culture and H istory, "Buddhism and Chinese Culture", Beijing, China Book Company.

Eit el , E. J. (1904): Handbook of Chinese Buddhism, 2nd edition, Tokyo, Sanshusha.

Fan, Shouyi (1991): "Ever Since Yan Fu and H is Criteria of Translation", Translation: Theory and Practice-Tension and Interdependence, ATA Scholarly Monograph, Series V, New York, SUNY. 
- - (1992): "A Linguistic Study of 'Treaty of Nanking' and 'Treaty of Wang-Hea',', Journal of Foreign Affairs College.

Fang, Le-tien (1957): Beginner's Translation Handbook, Hong Kong, The Commercial Press (HK).

Fu, Zhongxuan (1996): The Practical Translation Aesthetics, Shanghai, Shanghai Foreign Languages Education Publishing House.

Gemet, Jacques (1972/1986): A History of Chinese Civilization, Cambridge University Press.

H ou, Wailu (1957): A Developmental History of Chinese Thought, Beijing, The People' Publishing House.

H u, Shi (1929/1986): A History of Vernacular Literature, Changsha, Yuelu Publishing House.

H u , Tsi-Tan (1980): International Translation H andbook, Taibei, The International Cultural Enterprise Company.

H uang, Kai (1991): Structures and Translation M odels of Scientific English, Volumes 1-3, Taibei, Xiao Yuan Publishing Co.

H suan, Chien-jen (1986/1996): Jiu Mo Luo Shi: The Great Translator of Buddhist Classics, Gaoxiong, The Buddha's Halo Press.

Inspector General of Customs (1917): Treaties, Conventions, etc., Between China and Foreign States, Shanghai, The Statistical Department of the Inspector General of Customs, Volume 1.

Jin, Di (1989): On Equal-Effect Translation, Beijing, China Translation and Publishing Corporation.

Li, Chien-ying (1983): News English: Reading, Translation and Writing, Taibei, Ching Shih Publishing House.

Li, N anqiu (1981): "Preliminary Survey of Sci-tech Translation in the Late Q ing Period", Translation Bulletin, 2.

- - (1993): The History of Science Document Translation in China, Hefei, China Science and Technology University Press.

Liang, Qichao (1932/1990): Yinbingshi Collected Works, Beijing, China Book Company.

Liu, Miqing (1990): Studies on Translation Today, Nanchang, Jiangxi Education Press, revised ed. Taibei, Shu Lin Publishing Co. 1993.

- - (1995): Introduction to Translation Aesthetics, Taibei, Shu Lin Publishing Co.

Lu, Dianyang (1958/1959): Translation: Its Principles and Technique, Beijing, The Times Press.

Lu 0, Si (1979) English-Chinese and Chinese-English: A N ew Translation Handbook, Hong Kong, The Commercial Press (HK).

Lu, Zheng (1979): Lectures on the Origins of Chinese Buddhism, Beijing, China Book Company. Lu o, Xinzhang (Ed.) (1984): Essays on Translation, Beijing, The Commercial Press.

M a, Zuyi (1984): A Short History of Translation in China (Prior to the May Fourth M ovement), Beijing, China Translation and Publishing Corporation.

Pei, Yuan (1983): A Study of Historical Facts of Translation of Buddhist Classics: An O utline History of Translation in China (Part I), Taibei, Da Sheng Cultural Press.

Q ian, Cunxun (1954/1986): Western Impact on China through Translation, In Document, 1986, n' 2.

Qian, Zhongshu (1963): “Lin Shu's Translations”, Luo (Ed.) 1984, Essays on Translation, Beijing, The Commercial Press.

Ren, Jiyu (1985): A History of Buddhist Religion in China, Beijing, Chinese Social Sciences Press. Sh en, Dan (1995): Literary Stylistics and Fictional Translation, Beijing, Beijing University Press.

Sun, Changwu (1988): Buddhism and Chinese Literature, Shanghai, Shanghai People's Publishing House.

Sun, Zhili (1996): 1949-1966: On Translations of British and American Literatures of the PRC, Nanjing, The Yilin Press.

Tan, Zaixi (1991): A Short History of Translation in the West, Beijing, The Commercial Press.

Tang, Yongtong (1955/1983): A History of Buddhism in the Han, Wei, Western and Eastern Jin Dynasties, and the Southern and Northern Dynasties, Beijing, China Book Company.

Wang, Kefei (1997): Studies of Translation in a Cultural Context, Shanghai, Shanghai Foreign Language Education Press. 
Wang, Jia-shi and San-yi Huang (1969): Translating the News, Taibei, The Journalists Association.

Wang, Wen-yen (1984): A Study of the Translation of the Buddhist Canon, Taibei, Tian Hua Publishing Co.

W u, Xinxiang and Hongan Li (1990): Explorations in Equal Value Translation, Nanchang, Jiangxi Education Press.

Xi, Yongji (1992): A Comparative Study of Translation Aesthetics, Nanjing, The Nanjing Press.

Xiong, Yuezhi (1994): The Dissemination of Western Learning and Late Q ing Society, Shanghai, Shanghai People's Press.

Yu, Wen-ching (1976): Translation of Law: Its Principles and Technique, Hong Kong, Ta Kai Publishing $\mathrm{C} 0$. 